\title{
Recency Negativity: Newer Food Crops are Evaluated Less Favorably
}

\author{
Yoel Inbar and Jordan Phelps \\ University of Toronto \\ Paul Rozin \\ University of Pennsylvania
}

\begin{abstract}
Author Note
Address correspondence to Yoel Inbar, Department of Psychology, University of Toronto, yoel.inbar@utoronto.ca. Data, materials, and analysis scripts are available at https://osf.io/937hd/. This research was supported by the Social Sciences and Humanities Research Council of Canada (Insight Grant \# 435-2017-0304). The authors thank the members of the University of Toronto Morality Lab for their comments and suggestions.
\end{abstract}




\title{
RECENCY NEGATIVITY
}

\begin{abstract}
Food crops produced by new technologies such as genetic engineering are widely opposed (Gaskell, Bauer, Durant \& Allum, 1999; Scott, Inbar, Wirz, Brossard \& Rozin, 2018). Here, we examine one reason for this opposition: recency. More recently-developed crops are evaluated less favorably, whether they are produced by artificial selection (i.e., conventional breeding), natural or man-made irradiation, or genetic engineering. Negative effects of recency persist in a within-subjects design where people are able to explicitly compare crops developed at different times, and an internal meta-analysis shows that the negative effect of recency is robust across measures and stimuli. These results have implications for the evaluation of crops produced using new modification techniques, including the widespread opposition to genetic engineering.
\end{abstract}




\section{RECENCY NEGATIVITY}

\section{Recency Negativity: Newer Food Crops are Disliked More}

Humans have been altering the plant genome through artificial selection for roughly the past 10,000 years (Zohary, Hopf, \& Weiss, 2012), but the past century has seen significant advances in crop production resulting from new modification techniques. These include more intense forms of human selection, including well-known technologies such as genetic engineering (GE), but also older, lesser-known technologies such as forced mutation through irradiation or chemical exposure (Ahloowalia, Maluszynski, \& Nichterlein, 2004; NAS, 2016; Wieczorek \& Wright, 2012). Scientists are also developing next-generation gene editing techniques such as CRISPR-Cas9, which will allow more precise changes to organisms' genomes (Adli, 2018). New crop production technologies have already shown significant benefits — such as herbicide and pest resistance - to agricultural producers in both developing and developed countries (Klümper \& Qaim, 2014). However, future applications could particularly benefit people in the developing world by making staple crops more pest-resistant, drought-tolerant, or vitamin-rich (Tang, Dolnikowski, Russel \& Grusak, 2009; Guleria, Kumar \& Guleria, 2017; Yang et al., 2017; Narayanan et al., 2019).

One of the major obstacles to the use of these technologies has been not technical, but social. Particularly for GE crops, there has been widespread public skepticism, which is prevalent at least in the developed world, and particularly strong in Europe (Gaskell, Bauer, Durant \& Allum, 1999; Frewer et al., 2013; Scott, Inbar \& Rozin, 2016, 2019; Pew Research Center, 2016). This skepticism has persisted and even increased despite the scientific consensus that 1) the risks of GE crops to the environment are acceptable; 2) and the risks to human health are no greater than those posed by conventional agriculture (NAS, 2016). Because of the salience and importance of this public debate, there has been a substantial body of research examining 
RECENCY NEGATIVITY

attitudes towards GE food in particular (for a review, see Scott, Inbar, Wirz, Brossard \& Rozin, 2018). This research has uncovered a number of determinants of these attitudes, which can be divided into three broad areas: perceptions of risks (which are higher among opponents; Siegrist, 2000; Moon \& Balasubramanian, 2004); perceptions of benefits (which are lower among opponents; Gaskell et al., 2004; Traill et al., 2006); and trust in institutions that evaluate and regulate GE products (which is lower among opponents; Siegrist, 1999; Siegrist, 2000). All of these can be seen as rational or quasi-rational in that they involve weighing normatively defensible attitude inputs (for example, risk and benefit beliefs) to arrive at a considered judgment about the attitude object. More recently, research has been examining less normativelydefensible bases of GE food opposition, including moral objections to genetic engineering (Sjöberg, 2008; Scott et al., 2016, 2019) and lack of knowledge about biology and genetics (Fernbach, Light, Scott, Inbar \& Rozin, 2019).

Here, we examine a hitherto-unexplored motivation behind skepticism of novel crop production technologies, including genetic engineering: their recency. We were stimulated to explore this hypothesis by our puzzlement at the fact that domesticated entities are rated as much more natural than recently genetically modified entities (Rozin, 2005) even though domesticated plants (or animals) usually represent a much greater degree of genetic change than genetically engineered entities. (For example, a cocker spaniel is rated as much more natural than a pig with a single gene insertion.) We thought that what seemed to protect the domesticates might be that this process happened a long time ago.

We therefore hypothesize that the mere fact that a particular crop was developed more recently (as opposed to longer ago) will render it less acceptable to consumers. In the current research, we test this hypothesis for crops produced using a variety of techniques, including 
RECENCY NEGATIVITY

genetic engineering, natural and artificial irradiation, and even conventional breeding. Next, we outline the theoretical rationale behind the "recency negativity" hypothesis.

\section{Recency Negativity: Theoretical rationale}

There is converging evidence suggesting that recency might play a role in aversion to some crop production technologies. First, food is an area in which cultural traditions and heritage are particularly important. Cultures have strong norms around what can be eaten and what theoretically edible entities must be avoided, as well as how foods are prepared (Rozin, Cohen \& Ruby, 2019), and many of these traditions are hundreds or even thousands of years old.

Observant Hindus, for example, find the idea of eating beef repugnant, observant Jews will eat beef but are repulsed by pork, and many secular Americans eat beef and pork but are repulsed by the notion of eating horse (Roth, 2007). Indeed, a motivation to adhere to traditional cultural norms regarding what can be eaten and how food is prepared may have served an adaptive function by helping our ancestors avoid pathogens and parasites and consume a time-tested nutrient-balanced diet — at the cost, of course, of limiting the food repertoire (Boyd \& Richerson, 1985; Billing \& Sherman, 1998; Navarrete \& Fessler, 2003; Henrich \& Henrich, 2010). In the developed world, this food traditionalism manifests as a preference for "natural" or "heirloom" crops and minimal processing (Román, Sánchez-Siles \& Siegrist, 2017; Rozin, 2005; Scott \& Rozin, 2017).

Second, there is a substantial literature on the importance of food novelty as a basis for food rejection. ${ }^{1}$ All else equal, people like a food more the more they have tried it (Pliner, 1982), which is a specific case of the more general phenomenon of "mere exposure," where repeated

\footnotetext{
${ }^{1}$ Of course, although novelty and recency are positively correlated, they are in principle separable; for example, many people are averse to consuming (to them) exotic foods which have been actively consumed in other cultures for centuries or millennia.
} 


\section{RECENCY NEGATIVITY}

exposure to a stimulus tends to increase liking for it (Zajonc, 1968). The individual-differences variable of "food neophobia" further suggests that food novelty is inherently aversive to some people. Food neophobia is defined as the avoidance of novel or unfamiliar (i.e., unknown) foods, and is correlated with avoidance and negative expectations of novel foods as well as lower liking of them (Arvola, Lähteenmäki \& Tuorila, 1999; Pliner \& Hobden, 1992; Pliner, Lähteenmäki \& Tuorila, 1998). Food neophobic people are less likely to enjoy novel foods and integrate them into their diets even after being persuaded to try them. Unsurprisingly, then, the diets of those high in food neophobia are relatively homogenous (Koivisto \& Sjödén, 1996; Perry et al., 2015). The related Food Technology Neophobia Scale, which is intended to specifically measure skepticism of new food technologies (e.g., "The benefits of new food technologies are often grossly overstated"; Cox \& Evans, 2008) does indeed predict reluctance to consume foods produced using new technology, including GE foods (Evans, Kermarrec, Sable \& Cox, 2010; Matin et al., 2012; Vidigal et al., 2015

Finally, when it comes to risk perceptions more broadly, perceived newness seems to play a role in risk judgments. The "psychometrics of risk perception" literature (Fischhoff, Slovic, Lichtenstein, Read \& Combs, 1978; Slovic, Fischhoff, \& Lichtenstein, 1984, 1985) has found that perceptions of newness or novelty of a hazard correlate with perceived lack of knowledge about the hazard, involuntariness of exposure, and delayed effects. Together, these perceptions constitute what is known as the "unknown risk" factor in risk perceptions. Higher perceptions of unknown risk are associated with greater perceived risk overall, greater desire to reduce risk, and greater endorsement of regulations of the hazardous activity (Slovic, Fischhoff, \& Lichtenstein, 1985). 
RECENCY NEGATIVITY

There is thus theoretical motivation for the idea that recency of development will decrease consumer acceptance of a food crop-a phenomenon we call "recency negativity." Note that this is distinct from wariness of new food technologies (as measured, for example, by the Food Technology Neophobia Scale), because we hypothesize that even keeping the production technology constant, more recently-developed crops will be evaluated less favorably. We define "favorability" primarily as willingness to consume the crop in question, because of this question's direct relevance to consumer behavior. However, across studies we also ask participants to evaluate the crops on other dimensions including risk, benefits, moral acceptability, and naturalness.

Across four studies (and another 7 in the Supplemental Material), we find negative effects of recency on evaluations for crops produced by conventional breeding (Studies 1-2), gene insertion (Study 3), and natural and artificial radiation (Studies 1-4). We also show that the recency negativity effect holds across different lengths of time, different crop traits, and between- vs. within-participant designs.

Open Data and Materials. Data, materials, and analysis scripts are available at https://osf.io/937hd/.

\section{Study 1}

In Study 1, we tested the recency negativity hypothesis by asking participants to evaluate a hypothetical food crop said to have been developed either recently or 200 years ago. In order to generalize across different methods of genetic modification, we described the plant as having been produced by conventional breeding or by irradiation. We did not think that participants would believe that the technology to produce artificial radiation existed 200 years ago (as indeed it did not), so we described the radiation as naturally-occurring. We expected that consumers 
RECENCY NEGATIVITY

would evaluate the recently-modified plant more negatively, and that this would be true regardless of modification method.

\section{Participants and Procedure}

We set a target sample size of 400 participants from Amazon Mechanical Turk and obtained 402 complete responses $\left(57 \%\right.$ male; $\mathrm{M}_{\mathrm{age}}=36.71, \mathrm{SD}=11.59$; see Table 1 for complete demographics). This sample size was determined in advance based on a heuristic of $n=$ 100 per cell. Respondents were required to be U.S. residents.

In a between subject design, participants viewed one of four descriptions of a sweet potato plant accompanied by the same image of a sweet potato. Each description stated that the plant had undergone genetic change that made it larger and more drought-resistant, and that it was being grown for human consumption. Two factors were varied between descriptions: 1) whether the genetic modification resulted from conventional breeding or from exposure to naturally occurring gamma radiation that had entered earth's atmosphere from space; and 2) whether the plant had been modified recently or 200 years ago. For example, the plant modified recently was described as follows (text describing different modification methods is in brackets):

SP 6321 is a domesticated sweet potato (it does not grow wild in nature). Humans just recently [changed the DNA of SP 6321 's ancestors by selectively breeding only the largest and most drought-resistant sweet potato plants over multiple generations/grew one of SP 6321's ancestors outdoors where its DNA was altered by exposure to naturally occurring gamma rays that entered earth's atmosphere from space]. That DNA is in SP 6321 today, and it makes SP 6321 larger and more drought-resistant than many types of wild sweet potato. Farmers are just now beginning to grow SP 6321 for human consumption. 


\section{RECENCY NEGATIVITY}

Participants were then asked to rate their willingness to consume SP 6321. They were also asked how much risk they thought it posed (to them personally and to society), and how moral they thought it was to grow it (all on 7-point Likert scales). The exact questions were “How willing would you be to consume SP 6321?" (1 = “Completely unwilling," 4 = "Somewhat willing," 7 = “Completely willing”); "How much risk does growing SP 6321 pose to you personally?" (1 = "No risk at all," "4 = "Some risk," 7 = "A great deal of risk"); "How much risk does growing SP 6321 pose to society?" (1 = "No risk at all," "4 = "Some risk," 7 = "A great deal of risk"); "I think growing SP 6321 is" (1 = "Morally bad," 4 = "Morally neutral," $7=$ "Morally good"). They were also asked to rate how natural SP 6321 was on a 100-point scale modified from Rozin (2005), where a rating of zero meant completely unnatural and a rating of 100 meant completely natural. The order of these five items was randomized for each participant. 
RECENCY NEGATIVITY

Table 1

Participant demographics for Studies 1-4

\begin{tabular}{|c|c|c|c|c|}
\hline & Study 1 & Study 2 & Study 3 & Study 4 \\
\hline $\mathbf{N}$ & 402 & 402 & 801 & 203 \\
\hline \multirow[t]{2}{*}{ Age } & $M=36.71$ & $M=36.95$ & $M=36.82$ & $M=35.78$ \\
\hline & $\mathrm{SD}=11.59$ & $\mathrm{SD}=11.48$ & $\mathrm{SD}=12.87$ & $\mathrm{SD}=12.02$ \\
\hline \multicolumn{5}{|l|}{ Gender } \\
\hline Male & $229(57 \%)$ & $200(50 \%)$ & $326(41 \%)$ & $101(50 \%)$ \\
\hline Female & $173(43 \%)$ & $202(50 \%)$ & $471(59 \%)$ & $101(50 \%)$ \\
\hline Education & & & & \\
\hline $\begin{array}{c}\text { Less than High } \\
\text { School }\end{array}$ & $2(<1 \%)$ & $2(<1 \%)$ & $8(1 \%)$ & $0(0 \%)$ \\
\hline $\begin{array}{c}\text { High School or } \\
\text { GED }\end{array}$ & $40(10 \%)$ & $45(11 \%)$ & $95(12 \%)$ & $27(13 \%)$ \\
\hline $\begin{array}{c}\text { Associate's or } \\
\text { Technical } \\
\text { School }\end{array}$ & $29(7 \%)$ & $19(5 \%)$ & $52(6 \%)$ & $22(10 \%)$ \\
\hline Some College & $118(29 \%)$ & $102(25 \%)$ & $230(29 \%)$ & $55(27 \%)$ \\
\hline $\begin{array}{l}\text { Bachelor's } \\
\text { Degree }\end{array}$ & $152(38 \%)$ & $167(42 \%)$ & $289(36 \%)$ & $83(41 \%)$ \\
\hline $\begin{array}{c}\text { Some Graduate } \\
\text { School }\end{array}$ & $10(2 \%)$ & $10(2 \%)$ & $18(2 \%)$ & $4(2 \%)$ \\
\hline Higher Degree & $51(13 \%)$ & $56(14 \%)$ & $108(13 \%)$ & $12(6 \%)$ \\
\hline
\end{tabular}

\section{Results}

We conducted a 2 (time: recently vs. 200 years ago) x 2 (method: conventional breeding vs. natural radiation) factorial ANOVA separately for each item. As predicted, participants were less willing to consume the sweet potato when it had been developed recently, $F(1,398)=9.27$, $p=.002$. There was no effect of modification method, $F(1,398)=.06, p=.814$, and no time $\mathrm{x}$ method interaction, $F(1,398)=1.90, p=.169$. The more recent crop was evaluated as significantly riskier (both to the self and to society). For ratings of naturalness and morality, means were in the predicted directions (i.e., more negative for the recent crop), but neither difference was statistically significant. Descriptive statistics for each item by condition are 
RECENCY NEGATIVITY

shown in Table 2; the effects of time, method, and their interaction for each item are shown in Table 3.

Table 2

Descriptive statistics for all measures from Study 1

\begin{tabular}{ccccccccc}
\hline & $\begin{array}{c}\text { Domestication } \\
\text { (Recent) }\end{array}$ & \multicolumn{2}{c}{$\begin{array}{c}\text { Radiation } \\
\text { (Recent) }\end{array}$} & \multicolumn{2}{c}{$\begin{array}{c}\text { Domestication } \\
\text { (200 years) }\end{array}$} & \multicolumn{2}{c}{$\begin{array}{c}\text { Radiation } \\
\text { (200 years) }\end{array}$} \\
\hline Item & $\boldsymbol{M}$ & $\boldsymbol{S D}$ & $\boldsymbol{M}$ & $\boldsymbol{S D}$ & $\boldsymbol{M}$ & $\boldsymbol{S D}$ & Mean & $\boldsymbol{S D}$ \\
\hline $\begin{array}{c}\text { Willingness to } \\
\text { consume }\end{array}$ & 5.09 & 1.73 & 4.80 & 2.09 & 5.38 & 1.69 & 5.58 & 1.56 \\
\hline Naturalness & 62.25 & 29.31 & 60.77 & 32.97 & 65.10 & 30.93 & 67.13 & 28.14 \\
\hline Personal risk & 2.49 & 1.69 & 2.71 & 1.79 & 2.10 & 1.47 & 2.17 & 1.43 \\
\hline Societal risk & 2.79 & 1.68 & 2.93 & 1.81 & 2.20 & 1.47 & 2.51 & 1.58 \\
\hline Moral goodness & 4.89 & 1.47 & 4.68 & 1.70 & 4.98 & 1.58 & 5.00 & 1.40 \\
\hline
\end{tabular}

Table 3

Effects of time, modification method and their interaction on each measure from Study 1.

\begin{tabular}{ccccccc}
\hline & \multicolumn{2}{c}{ Time } & \multicolumn{2}{c}{ Method } & \multicolumn{2}{c}{ Time x Method } \\
\hline Item & $\boldsymbol{F ( 1 , 3 9 8 )}$ & $\boldsymbol{p}$ & $\boldsymbol{F ( 1 , \mathbf { 3 9 8 } )}$ & $\boldsymbol{p}$ & $\boldsymbol{F}(\mathbf{1 , 3 9 8 )}$ & $\boldsymbol{p}$ \\
\hline $\begin{array}{c}\text { Willingness to } \\
\text { consume }\end{array}$ & 9.27 & $.002^{*}$ & 0.06 & .814 & 1.90 & .169 \\
\hline Naturalness & 2.31 & .130 & 0.01 & .928 & 0.34 & .562 \\
\hline Personal risk & 8.63 & $.003^{*}$ & 0.79 & .375 & 0.20 & .654 \\
\hline Societal risk & 9.39 & $.002^{*}$ & 1.97 & .161 & 0.30 & .586 \\
\hline Moral goodness & 1.78 & .183 & 0.41 & .523 & 0.59 & .443 \\
\hline
\end{tabular}


RECENCY NEGATIVITY

\section{Discussion}

Our first test of the recency negativity hypothesis showed a statistically reliable negative effect of crop recency on people's willingness to consume it, holding the method of genetic modification constant. Collapsing across method of modification, the effect size of time was $d=$ .30. Additionally, participants saw the recently-developed crop as significantly riskier, both to themselves and to society. Somewhat remarkably, this effect was not moderated by method of modification, and there was no main effect of artificial selection vs. radiation on crop evaluations. This may be because the radiation was described as natural rather than artificiallygenerated (Rozin, 2005).

\section{Study 2}

In Study 2, we tested the recency negativity hypothesis by asking participants to evaluate a hypothetical food crop plant said to have been developed either recently or 100 (rather than 200) years ago. We changed the time for the older crop both to make the method of development plausible (see below), and to explore the robustness of the effect to varying amounts of time. As in Study 1, we described one plant as having been produced by conventional breeding, but to further generalize across modification methods we described another plant as having been produced by exposure to man-made (i.e. lab-generated) radiation. We again expected that the plant would be judged more negatively if it had been modified recently. Further, while Study 1 revealed no difference in judgments between plants produced by conventional breeding and naturally-occurring radiation, we expected that plants produced by man-made radiation would be judged more negatively, consistent with a general dislike of human intervention in the food domain (Rozin, 2005; Scott \& Rozin, 2017).

\section{Participants and Procedure}


RECENCY NEGATIVITY

We set a target sample size of 400 participants from Amazon Mechanical Turk and obtained 402 complete responses $\left(50 \%\right.$ male; $\mathrm{M}_{\mathrm{age}}=36.95, \mathrm{SD}=11.48$; see Table 1 for complete demographics). Sample size was determined in advance using the same heuristic as in Study 1. Respondents were required to be U.S. residents and had not participated any other studies in this line of research.

Participants viewed one of four descriptions of a sweet potato plant accompanied by an image of a sweet potato. Each description stated that the plant had undergone genetic change that made it larger and more drought-resistant, and that it was being grown for human consumption. Two factors were varied between descriptions: 1) whether the plant had been produced by conventional breeding or through exposure to gamma radiation generated by humans for the purpose of inducing genetic change; and 2) whether the plant had been modified recently or 100 years ago.

Participants responded to the same five items used in Study 1; item order was randomized for each participant. Following this, participants were asked to rate how different the DNA of SP 6321 was from DNA of its ancestors using a 7-point Likert scale $(1=$ "Not at all different," $4=$ "Somewhat different," 7 = "Completely different").

\section{Results}

We conducted a 2 (time: recently vs. 100 years ago) x 2 (method: conventional breeding vs. radiation) ANOVA separately for each item. As in Study 1, participants were less willing to consume the sweet potato when it had been modified recently, as opposed to 100 years ago, $F(1$, $398)=24.59, p<.001$. The recently-modified sweet potato was also rated as significantly less natural and as riskier for participants personally and for society; growing the recently-developed sweet potato was also rated as significantly less moral. Unlike Study 1, there were significant 
RECENCY NEGATIVITY

effects of modification method, such that the artificially-irradiated sweet potato was rated more negatively on all items, but this did not interact with time (see Table 4 for descriptive statistics by item and Table 5 for all inferential tests).

To examine whether these more negative evaluations were the result of participants inferring that irradiated or recently-developed crops had undergone greater genetic change, we conducted an additional 2 (time: recently vs. 100 years ago) x 2 (method: conventional breeding vs. radiation) ANOVA on ratings of perceived genetic change. There was no effect of time, $F(1$, $398)=0.03, p=.86$, or modification method, $F(1,398)=1.17, p=.28$, and no time $\mathrm{x}$ modification method interaction, $F(1,398)=1.07, p=.30 ; M_{\text {recently } / \text { conventional breeding }}=4.46, S D=$ $1.26 ; M_{\text {recently/radiation }}=4.31, S D=1.28 ; M_{100 \text { years } / \text { conventional breeding }}=4.19, S D=1.24 ; M_{100}$ years/radiation $=4.30, S D=1.42$. 
RECENCY NEGATIVITY

Table 4

Descriptive statistics for all measures from Study 2

\begin{tabular}{ccccccccc}
\hline & \multicolumn{2}{c}{$\begin{array}{c}\text { Domestication } \\
\text { (Recent) }\end{array}$} & \multicolumn{2}{c}{$\begin{array}{c}\text { Radiation } \\
\text { (Recent) }\end{array}$} & \multicolumn{2}{c}{$\begin{array}{c}\text { Domestication } \\
\text { (100 years) }\end{array}$} & \multicolumn{2}{c}{$\begin{array}{c}\text { Radiation } \\
\text { (100 years) }\end{array}$} \\
\hline Item & Mean & SD & Mean & SD & Mean & SD & Mean & SD \\
\hline $\begin{array}{c}\text { Willingness to } \\
\text { consume }\end{array}$ & 4.82 & 1.93 & 3.54 & 1.90 & 5.66 & 1.61 & 4.53 & 1.88 \\
\hline Naturalness & 54.73 & 30.98 & 46.64 & 29.00 & 63.32 & 32.07 & 55.51 & 30.45 \\
\hline Personal risk & 2.85 & 1.76 & 3.52 & 1.67 & 2.20 & 1.61 & 2.85 & 1.76 \\
\hline Societal risk & 3.06 & 1.61 & 3.82 & 1.71 & 2.14 & 1.40 & 3.14 & 1.63 \\
\hline Moral goodness & 4.65 & 1.61 & 3.78 & 1.57 & 5.09 & 1.44 & 4.34 & 1.63 \\
\hline $\begin{array}{c}\text { Perceived genetic } \\
\text { change }\end{array}$ & 4.46 & 1.26 & 4.31 & 1.28 & 4.19 & 1.24 & 4.30 & 1.42 \\
\hline
\end{tabular}

Table 5

Effects of time, modification method and their interaction on each measure from Study 2

\begin{tabular}{ccccccc}
\hline & \multicolumn{2}{c}{ Time } & \multicolumn{2}{c}{ Method } & \multicolumn{2}{c}{ Time x Method } \\
\hline Item & $\boldsymbol{F ( 1 , 3 9 8 )}$ & $\boldsymbol{p}$ & $\boldsymbol{F ( 1 , 3 9 8 )}$ & $\boldsymbol{p}$ & $\boldsymbol{F ( 2 , 3 9 8 )}$ & $\boldsymbol{p}$ \\
\hline $\begin{array}{c}\text { Willingness to } \\
\text { consume }\end{array}$ & 24.59 & $<.001^{*}$ & 43.03 & $<.001^{*}$ & 0.18 & .669 \\
\hline Naturalness & 8.14 & $.005^{*}$ & 6.75 & $.010^{*}$ & $<0.01$ & .964 \\
\hline Personal risk & 15.19 & $<.001^{*}$ & 15.11 & $<.001^{*}$ & $<0.01$ & .961 \\
\hline Societal risk & 25.24 & $<.001^{*}$ & 30.87 & $<.001^{*}$ & 0.59 & .443 \\
\hline Moral goodness & 10.41 & $.001^{*}$ & 26.98 & $<.001^{*}$ & 0.14 & .704 \\
\hline $\begin{array}{c}\text { Perceived genetic } \\
\text { change }\end{array}$ & 1.17 & .280 & 0.03 & .865 & 1.07 & .301 \\
\hline
\end{tabular}

\section{Discussion}

Our second test of the recency negativity hypothesis also showed a strong and negative effect of crop recency on evaluations, holding the method of genetic modification constant. There was also a significant effect of modification method, such that plants modified by manmade radiation were judged more negatively than those modified by conventional breeding. 
RECENCY NEGATIVITY

Importantly, however, there was no interaction: recency was just as negative for conventionallybred crops as for crops produced by irradiation. In terms of Cohen's $d$, the effect size of time (collapsing across modification method) was $d=.45$; for comparison the effect of modification method (collapsing across time) was $d=.65$.

Notably, the negativity to genetic modification was markedly reduced at the longer time. For example, willingness to consume the artificially irradiated plant moved from below the scale midpoint when the irradiation was recent $(M=3.54, S D=1.90)$ to above it when the irradiation had happened 100 years ago $(M=4.53, S D=1.88)$. Likewise, participants rated the morality of growing the irradiated plant below the scale midpoint (labelled "morally neutral") when the irradiation was recent $(M=3.78, S D=1.57)$, to above it when it had happened 100 years ago $(M$ $=4.34, S D=1.63)$.

\section{Study 3}

The results of Study 2 suggest that modified plants are judged more negatively when modification results from invasive human involvement. In Study 3, we tested for differences between two distinct modification methods of invasive human involvement: exposure to humangenerated gamma radiation to induce genetic change (a method that has been used since the 1930s but is relatively unknown to the public; Ahloowalia, Maluszynski, \& Nichterlein, 2004), and the insertion of a gene to introduce a specific trait (a method that has received a great deal of negative attention in the public discourse; Scott, Inbar, Wirz, Brossard, \& Rozin, 2018). We also again reduced the modification timeframe for the older crop (to 25 years ago). This both tested for a possible boundary condition and made gene insertion a plausible modification method.

We pre-registered the sample size, design, and analyses for this study at https://aspredicted.org/t9bh6.pdf. 
RECENCY NEGATIVITY

\section{Participants and Procedure}

We set a target sample size of 800 participants from Amazon Mechanical Turk and obtained 801 complete responses $\left(59 \%\right.$ female; $\mathrm{M}_{\mathrm{age}}=36.82, \mathrm{SD}=12.87$; see Table 1 for complete demographics). This larger sample size was determined based on pilot testing of this study (this pilot is described in the Supplemental Material). Respondents were required to be U.S. residents and had not participated any other studies in this line of research.

Participants viewed one of four descriptions of a corn plant accompanied by an image of corn. Each description stated that the plant had undergone genetic change that allowed it to produce a chemical defense that targets and kills pest insects that feed on corn. Two factors were varied between descriptions: 1) whether the plant had been modified through exposure to gamma radiation generated by scientists for the purpose of inducing genetic change or through a modern genetic engineering technique that allowed scientists to insert a specific gene from a bacterium into the plant, and 2) whether the plant had been modified recently or 25 years ago. For example, the plant modified 25 years ago through gene insertion was described as follows:

C 6321 is a domesticated variety of corn (it does not grow wild in nature). Twenty-five years ago, scientists changed the DNA of C 6321's ancestors by inserting a gene from a bacterium using laboratory genetic engineering techniques. The added gene allows $C$ 6321 to produce a chemical defense that specifically targets and kills common insect pests that feed on corn. That DNA is in C 6321 today, and it makes C 6321 more pestresistant than many other varieties of corn. Farmers have grown C 6321 for human consumption ever since.

Participants completed the same five evaluative items used in Studies 1 and 2; the order

of these was randomized for each participant. Following this, participants were asked to rate how 
RECENCY NEGATIVITY

different the DNA of C 6321 was from DNA of its ancestors (on the same 7-point Likert scale described in Study 2).

\section{Results}

We conducted a 2 (time: recently vs. 25 years ago) x 2 (method: gene insertion vs. radiation) ANOVA separately for each item. As in the previous studies, participants were less willing to consume the corn when it had been modified recently, as opposed to 25 years ago, $F(1$, $797)=21.25, p<.001$ (collapsing across modification methods, the effect of time was $d=.32$ ). The recently-modified corn was also rated as significantly less natural and as riskier for participants personally and for society; growing the recently-developed corn was also rated as significantly less moral. There were no significant effects of modification method and no interactions with time (see Table 6 for descriptive statistics by item and Table 7 for all inferential tests).

We conducted an additional 2 (time: recently vs. 25 years ago) x 2 (method: radiation vs. gene insertion) ANOVA on ratings of perceived genetic change. There was no effect of time, $F(1,797)=0.96, p=.33$, or modification method, $F(1,797)=2.07, p=.15$, and no time $\mathrm{x}$ method interaction, $F(1,797)=2.74, p=.09$.

\section{Deviations from preregistration}

Due to an oversight, we did not preregister the inclusion of the genetic change item, but we did not predict differences for this item. 
RECENCY NEGATIVITY

Table 6

Descriptive statistics for all measures from Study 3

\begin{tabular}{ccccccccc}
\hline Item & \multicolumn{2}{c}{$\begin{array}{c}\text { Radiation } \\
\text { (Recent) }\end{array}$} & \multicolumn{2}{c}{$\begin{array}{c}\text { Gene insertion } \\
\text { (Recent) }\end{array}$} & \multicolumn{2}{c}{$\begin{array}{c}\text { Radiation } \\
\text { (25 years) }\end{array}$} & \multicolumn{2}{c}{$\begin{array}{c}\text { Gene insertion } \\
\text { (25 years) }\end{array}$} \\
\hline & Mean & SD & Mean & SD & Mean & SD & Mean & SD \\
\hline $\begin{array}{c}\text { Willingness to } \\
\text { consume }\end{array}$ & 3.64 & 1.91 & 3.79 & 1.87 & 4.21 & 2.00 & 4.49 & 1.93 \\
\hline Naturalness & 39.16 & 27.01 & 42.97 & 27.90 & 45.04 & 30.74 & 46.67 & 30.67 \\
\hline Personal risk & 3.72 & 1.71 & 3.52 & 1.69 & 3.33 & 1.85 & 3.28 & 1.75 \\
\hline Societal risk & 3.99 & 1.66 & 3.86 & 1.49 & 3.63 & 1.80 & 3.54 & 1.64 \\
\hline $\begin{array}{c}\text { Moral goodness } \\
\text { Perceived genetic } \\
\text { change }\end{array}$ & 3.71 & 1.62 & 3.80 & 1.47 & 4.02 & 1.69 & 4.15 & 1.55 \\
\hline \begin{tabular}{c} 
Pernency \\
\hline
\end{tabular} & 1.28 & 4.74 & 1.27 & 4.51 & 1.34 & 4.81 & 1.42 \\
\hline
\end{tabular}

Table 7

Effects of time, modification method and their interaction on each measure from Study 3

\begin{tabular}{ccccccc}
\hline Item & \multicolumn{2}{c}{ Time } & \multicolumn{2}{c}{ Method } & \multicolumn{2}{c}{ Time x Method } \\
\hline & $\boldsymbol{F ( 1 , 7 9 7 )}$ & $\boldsymbol{p}$ & $\boldsymbol{F ( 1 , 7 9 7 )}$ & $\boldsymbol{p}$ & $\boldsymbol{F ( 1 , 7 9 7 )}$ & $\boldsymbol{p}$ \\
\hline $\begin{array}{c}\text { Willingness to } \\
\text { consume }\end{array}$ & 21.25 & $<.001^{*}$ & 2.48 & .116 & 0.24 & .623 \\
\hline Naturalness & 5.41 & $.020^{*}$ & 1.74 & .188 & 0.28 & .597 \\
\hline Personal risk & 6.47 & $.011^{*}$ & 0.99 & .319 & 0.31 & .580 \\
\hline Societal risk & 8.65 & $.003^{*}$ & 0.96 & .328 & 0.03 & .869 \\
\hline Moral goodness & 8.73 & $.003^{*}$ & 0.93 & .335 & 0.02 & .879 \\
\hline $\begin{array}{c}\text { Perceived genetic } \\
\text { change }\end{array}$ & 0.96 & .326 & 2.07 & .150 & 2.74 & .098 \\
\hline
\end{tabular}




\section{RECENCY NEGATIVITY}

\section{Discussion}

Our third test provided additional support for the recency negativity hypothesis; even when compared with a crop modified only 25 years ago, people evaluate recently modified crops less positively. As in Study 2, evaluations of both types of crops were below the scale midpoint when the crop was modified recently; willingness to consume $\left(M_{\text {radiation }}=3.64, S D_{\text {radiation }}=1.91\right.$; $\left.M_{\text {gene insertion }}=3.79, S D_{\text {gene insertion }}=1.87\right) ;$ moral goodness $\left(M_{\text {radiation }}=3.71, S D_{\text {radiation }}=1.62 ;\right.$ $\left.M_{\text {gene insertion }}=3.80, S D_{\text {gene insertion }}=1.47\right)$. When the crop was modified 25 years ago, evaluations were above the midpoint for both modification types and items; willingness to consume $\left(M_{\text {radiation }}=4.21, S D_{\text {radiation }}=2.00 ; M_{\text {gene insertion }}=4.49, S D_{\text {gene insertion }}=1.93\right) ;$ moral goodness $\left(M_{\text {radiation }}=4.02, S D_{\text {radiation }}=1.69 ; M_{\text {gene insertion }}=4.15, S D_{\text {gene insertion }}=1.55\right)$.

Again, the effect of recency was not moderated by modification technique. In fact, in this study there was not a main effect of modification technique (i.e., gene insertion vs. radiation) despite a sample size that gave us $80 \%$ power to detect an effect size of $d=.20$. Artificial radiation and gene insertion are both relatively invasive and "unnatural" techniques, but, nonetheless, these results suggest that people may be less specifically sensitive to genetic modification techniques than research has previously assumed.

\section{Study 4}

Studies 1-3 provided evidence for a consistent negative effect of recency on crop evaluations. This was the case for different crops, different modification techniques, and different amounts of time (200 vs. 100 vs. 25 years ago). All studies, thus far, however, used between-subjects designs. In Study 4, we tested the recency negativity effect using a withinsubject design in which all participants saw three different plants: one modified recently, one modified 25 years ago, and one modified 100 years ago. This design had two desirable features. 


\section{RECENCY NEGATIVITY}

First, it allowed us to test whether people maintained different evaluations when they explicitly compared crops modified at different times. If they did not (i.e., if there were no effects of time within-subjects), this would indicate that people believe that time normatively should not affect their judgments (see Hsee, Loewenstein, Blount, \& Bazerman, 1999). Second, it gave us the statistical power to detect dose sensitivity to time, if it existed (e.g., is a plant modified 100 years ago more acceptable than one modified 25 years ago?).

\section{Participants and Procedure}

We set a target sample size of 200 participants from Amazon Mechanical Turk and obtained 203 complete responses $\left(50 \%\right.$ male; $\mathrm{M}_{\mathrm{age}}=35.78, \mathrm{SD}=12.02$; see Table 1 for complete demographics). This sample size was determined in advance to maintain $n=100$ for the between-subjects comparison (see below). Respondents were required to be U.S. residents and had not participated any other studies in this line of research.

Participants viewed three descriptions and pictures of different (but similar-looking) corn plants. One plant (C 6321) was described as having been modified recently, one (C 5438) as having been modified 25 years ago, and one (C 4782) as having been modified 100 years ago. In order to increase realism, we described each of these plants as having been modified by humangenerated gamma radiation to introduce one of three traits (improved taste, texture or shelf-life). Traits were paired randomly with plant, such that each participant saw each trait once in random order (this avoided confounding trait with modification time, since traits were randomly paired with modification time for each participants). Participants were randomly assigned to see plants either in descending or ascending order of modification time. That is, participants either saw the plant modified 100 years ago, then the plant modified 25 years ago, then the plant modified recently; or they saw the reverse order. This allowed for a between-subjects test of evaluations of 
RECENCY NEGATIVITY

the plant participants saw first, which was always either the plant modified 100 years ago vs. the plant modified recently. This between-subjects test is a conceptual replication of the effect tested Studies 1-3.

After reading each description, participants completed the same five evaluative items used in the previous studies. They were also asked to rate how disgusted they were by the idea of growing C 6321 for human consumption, how angered they were, and how beneficial they thought growing it was (to them personally and to society; all on 7-point Likert scales). The exact questions were "How disgusted are you by the idea of growing C 6321 for human consumption?" (1 = "Not at all disgusted," 4 = "Somewhat disgusted," 7 = "Extremely disgusted"); "How angered are you by the idea of growing C 6321 for human consumption?" (1 $=$ "Not at all angered," 4 = "Somewhat angered," 7 = "Extremely angered"); "How beneficial is growing C 6321 to you personally?" (1 = "Not at all beneficial," "4 = "Somewhat beneficial," 7 = "Highly beneficial"); "How beneficial is growing C 6321 to society?" (1 = "Not at all beneficial," "4 = "Somewhat beneficial," 7 = "Highly beneficial"). The order of these nine items was randomized for each participant.

\section{Results}

We conducted 3 (time: recently, 25 years ago and 100 years ago) x 2 (presentation order: ascending vs. descending) mixed ANOVAs separately for each item. Table 8 shows complete results from these models; means and standard errors per condition for each question are shown in Figure 1. In general, participants evaluated more recently developed crops more negatively, although the effect of time was not significant for ratings of anger.

We examined trends across different amounts of time using paired $t$ tests comparing evaluations of crops developed recently to those developed 25 years ago, and those developed 25 
RECENCY NEGATIVITY

years ago to those developed 100 years ago. There was some variability across items in these results, but the clearest pattern is that evaluations become more negative moving from "recently" to 25 years; differences are less pronounced moving from 25 years to 100 . These results are shown in Table 9.

Finally, we conducted between-subjects $t$ tests comparing the first rating for participants in the ascending order condition to the first rating for those in the descending order condition. These tests are a conceptual replication of those in Studies 1-3 since participants in the descending condition always rated the plant developed 100 years ago first, and participants in the ascending order condition always rated the plant developed recently first. These tests were consistent with the results previous studies; there were significant differences for all items other than personal risk and disgust, which were marginally significant. These results are shown in Table 10. 


\section{RECENCY NEGATIVITY}

Figure 1. Corn evaluations by time and presentation order. Error bars represent standard error of the mean.

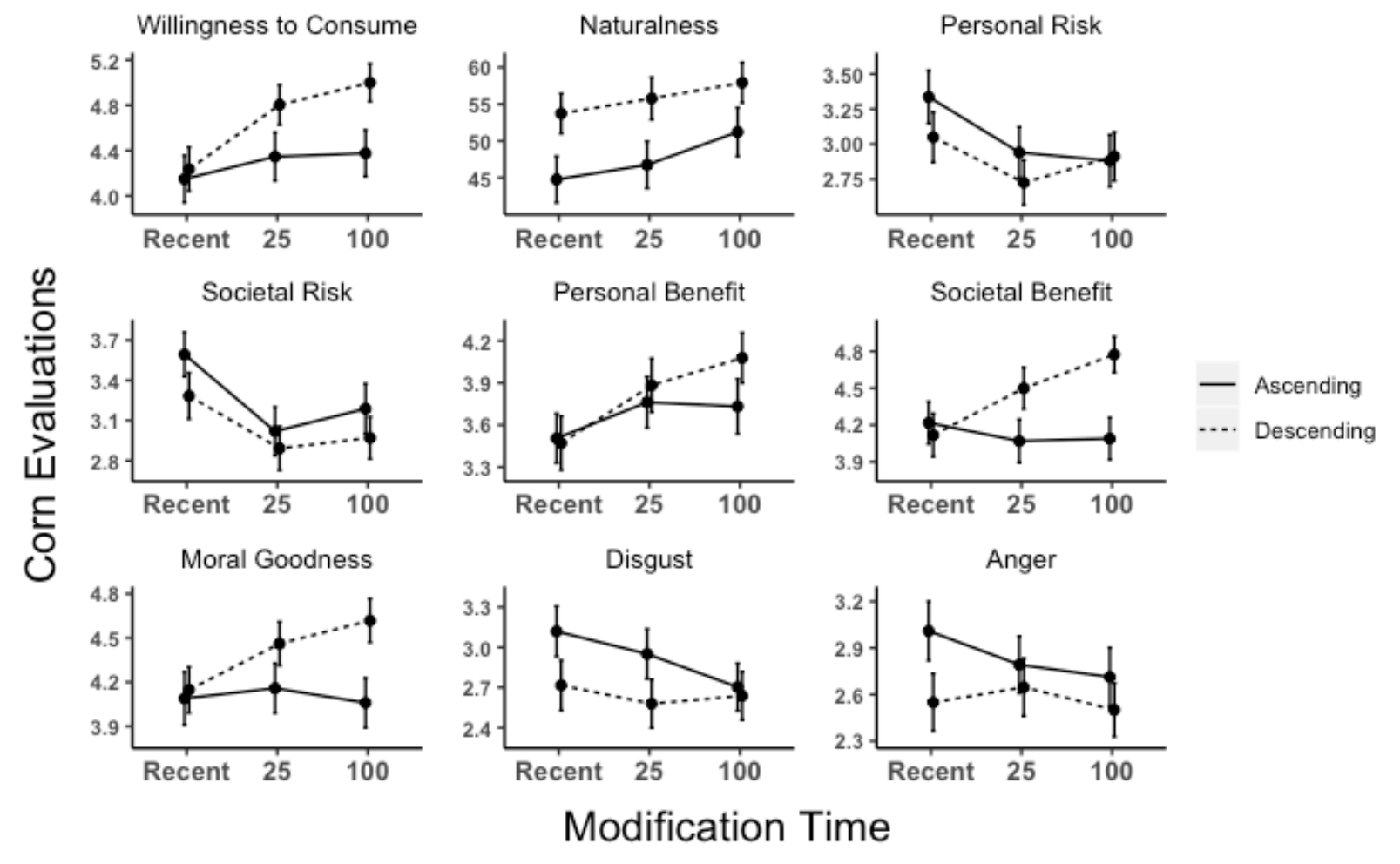

Table 8

Effects of time, order, and their interaction on each item in Study 4

\begin{tabular}{ccccccc}
\hline Item & \multicolumn{2}{c}{ Time } & \multicolumn{2}{c}{ Order } & \multicolumn{2}{c}{ Time x Order } \\
\hline & $\boldsymbol{F ( 2 , 4 0 2 )}$ & $\boldsymbol{p}$ & $\boldsymbol{F ( 1 , ~ 2 0 1 )}$ & $\boldsymbol{p}$ & $\boldsymbol{F ( 2 , \mathbf { 4 0 2 } )}$ & $\boldsymbol{p}$ \\
\hline $\begin{array}{c}\text { Willingness to } \\
\text { consume }\end{array}$ & 16.89 & $<.001$ & 2.33 & .129 & 4.81 & .009 \\
\hline Naturalness & 10.52 & $<.001$ & 4.18 & .042 & 0.64 & .528 \\
\hline Personal risk & 9.70 & $<.001$ & 0.46 & .497 & 1.83 & .161 \\
\hline Societal risk & 16.66 & $<.001$ & 0.98 & .323 & 0.55 & .578 \\
\hline Personal benefit & 10.66 & $<.001$ & 0.36 & .548 & 1.99 & .139 \\
\hline Societal benefit & 3.30 & .038 & 2.70 & .102 & 7.45 & $<.001^{*}$ \\
\hline Moral goodness & 4.97 & .007 & 2.09 & .150 & 5.37 & $.005^{*}$ \\
\hline Disgust & 4.57 & .011 & 1.35 & .247 & 2.57 & .078 \\
\hline Anger & 2.18 & .115 & 1.27 & .261 & 1.96 & .143 \\
\hline
\end{tabular}


RECENCY NEGATIVITY

Table 9

Differences in evaluations by time for each item in Study 4

\begin{tabular}{ccccc}
\hline \multicolumn{1}{c}{ Item } & \multicolumn{2}{c}{ Recently vs. 25 } & \multicolumn{2}{c}{$\mathbf{2 5}$ vs. 100 } \\
\hline $\begin{array}{c}\text { Willingness to } \\
\text { consume }\end{array}$ & 4.24 & $\boldsymbol{p}$ & $\mathbf{t ( 2 0 2 )}$ & $\boldsymbol{p}$ \\
\hline Naturalness & 1.82 & .001 & 1.41 & .160 \\
\hline Personal risk & 4.04 & .071 & 3.04 & $.003^{*}$ \\
\hline Societal risk & 6.03 & $<.001$ & 0.84 & .402 \\
\hline Personal benefit & 4.00 & $<.001$ & 1.50 & .136 \\
\hline Societal benefit & 1.03 & $<.001$ & 0.88 & .383 \\
\hline Moral goodness & 2.51 & .305 & 1.80 & .073 \\
\hline Disgust & 1.90 & .013 & 0.46 & .648 \\
\hline Anger & 0.66 & .059 & 1.22 & .226 \\
\hline
\end{tabular}

Table 10

First rating comparisons by order of presentation in Study 4

\begin{tabular}{ccc}
\hline Item & $\boldsymbol{t}(\mathbf{d f})$ & $\boldsymbol{p}$ \\
\hline Willingness to consume & $3.20(191.92)$ & .002 \\
\hline Naturalness & $3.15(196.78)$ & .002 \\
\hline Personal risk & $1.66(199.39)$ & .099 \\
\hline Societal risk & $2.74(200.47)$ & .007 \\
\hline Personal benefit & $2.29(201.00)$ & .023 \\
\hline Societal benefit & $2.46(195.51)$ & .015 \\
\hline Moral goodness & $2.26(193.67)$ & .025 \\
\hline Disgust & $1.85(200.54)$ & .066 \\
\hline Anger & $1.98(199.02)$ & .049 \\
\hline
\end{tabular}

\section{Discussion}

Study 4 uncovered consistent evidence for the recency negativity hypothesis using a within-subjects design and an expanded set of dependent variables. Follow-up tests showed that the largest decrease in crop evaluations occurred moving from a crop modified "just recently" to one modified 25 years ago. This non-linearity suggests that extreme crop novelty may be evaluated particularly negatively. That said, there were still differences in evaluations between 
RECENCY NEGATIVITY

crops modified 25 years and 100 years ago, suggesting that although the effect of greater time since modification on evaluations diminishes at the margin, it remains positive.

\section{Internal Meta-Analyses}

Although we observed consistent effects of time on crop evaluations across studies, comparisons were not statistically significant for every item in every study. In order to better determine the size of the effect of time across items, we conducted random-effects meta-analyses (using the metafor package in R; Viechtbauer, 2010) of the effect of modification time on each item. In addition to data from Studies 1-4, these meta-analyses include data from four supplementary studies, a pilot of Study 3 not reported in the main text, and two studies reported in the General Discussion; all these are described in Supplementary Material. Together, these are all the studies we ran using this design (i.e., asking people to compare recently-created crops to those created longer ago).

A brief description and date of completion for each study included in meta-analyses is provided in Table 11. While most measures were taken across all studies, there were some differences between studies; we report these differences along with results from the four metaanalyses in Tables 12 to 16 . 
Table 11

Studies included in meta-analyses

\begin{tabular}{|c|c|c|c|}
\hline Study & $\mathbf{N}$ & Description & Date \\
\hline 1 & 402 & $\begin{array}{l}2 \text { (Domestication vs. Natural Radiation) x } 2 \text { (Recently modified } \\
\text { vs. modified } 200 \text { years ago). All data are included. }\end{array}$ & $03 / 08 / 2019$ \\
\hline 2 & 402 & $\begin{array}{l}2 \text { (Domestication vs. Artificial Radiation) x } 2 \text { (Recently } \\
\text { modified vs. modified } 100 \text { years ago). All data are included. }\end{array}$ & $03 / 14 / 2019$ \\
\hline 3 & 801 & $\begin{array}{l}2 \text { (Gene Insertion vs. Artificial Radiation) x } 2 \text { (Recently } \\
\text { modified vs. modified } 25 \text { years ago). All data are included. }\end{array}$ & $08 / 02 / 2019$ \\
\hline 4 & 203 & $\begin{array}{l}\text { Artificial Radiation, Within Subjects (Modified recently, } 25 \\
\text { years ago and } 100 \text { years ago). Only first ratings are included. }\end{array}$ & $05 / 14 / 2019$ \\
\hline s1 & 201 & $\begin{array}{l}\text { Gene Insertion, } 2 \text { (Recently modified vs. modified } 25 \text { years } \\
\text { ago). All data are included. }\end{array}$ & $03 / 25 / 2019$ \\
\hline s2 & 402 & $\begin{array}{l}2 \text { (Positive vs. negative trait) x } 2 \text { (Recently modified vs. } \\
\text { modified } 100 \text { years ago). All data are included. }\end{array}$ & $04 / 08 / 2019$ \\
\hline s3 & 253 & $\begin{array}{l}\text { Artificial Radiation, } 5 \text { (Modified recently or } 25,50,75 \text { or } 100 \\
\text { years ago). Only ratings of recently modified plants and plants } \\
\text { modified } 100 \text { years ago are included. }\end{array}$ & $04 / 17 / 2019$ \\
\hline s4 & 508 & $\begin{array}{l}\text { Artificial Radiation, } 5 \text { (Modified recently or } 25,50,75 \text { or } 100 \\
\text { years ago). Only ratings of recently modified plants and plants } \\
\text { modified } 100 \text { years ago are included. }\end{array}$ & $04 / 25 / 2019$ \\
\hline p3 & 402 & $\begin{array}{l}2 \text { (Gene Insertion vs. Artificial Radiation) x } 2 \text { (Recently } \\
\text { modified vs. modified } 25 \text { years ago). All data are included. }\end{array}$ & $03 / 28 / 2019$ \\
\hline $\operatorname{gd1}$ & 914 & $\begin{array}{l}\text { Natural radiation (recently modified vs. modified } 200 \text { years ago } \\
\text { vs. modified } 200 \text { years ago and stored). Only data from the first } \\
\text { two conditions are included. }\end{array}$ & $01 / 20 / 2020$ \\
\hline $\operatorname{gd} 2$ & 912 & $\begin{array}{l}\text { Artificial radiation (recently modified vs. modified } 100 \text { years } \\
\text { ago vs. modified } 100 \text { years ago but not consumed until } \\
\text { recently). Only data from the first two conditions are included. }\end{array}$ & $01 / 23 / 2020$ \\
\hline
\end{tabular}

\section{Time}

Across studies, people showed a strong preference for crops that had been modified a longer time ago (Table 12). People were more willing to eat the less recently modified crops, they viewed them as more natural, less risky, more beneficial, and more morally good. People did not claim to be less disgusted or angered by the idea of growing them for human consumption compared with growing more recently modified crops, and there was no difference in perceived genetic change between crops grown more or less recently. Figure 2 shows 
RECENCY NEGATIVITY

standardized mean differences across studies for willingness to consume. Standardized mean difference forest plots are presented for all other measures in Supplementary Material.

Table 12

Meta-analysis results for the effect of time. Estimate is the standardized mean difference between conditions

\begin{tabular}{cccc}
\hline Measure & Studies & Estimate & $\boldsymbol{p}$ \\
\hline Willingness to consume & All $(\mathrm{k}=11)$ & -0.27 & $<.001^{*}$ \\
\hline Naturalness & All $(\mathrm{k}=11)$ & -0.17 & $<.001^{*}$ \\
\hline Personal risk & All $(\mathrm{k}=11)$ & 0.15 & $.001^{*}$ \\
\hline Societal risk & All $(\mathrm{k}=11)$ & 0.19 & $<.001^{*}$ \\
\hline Personal benefit & $4, \mathrm{~s} 1-4, \mathrm{p} 3(\mathrm{k}=6)$ & -0.24 & $<.001^{*}$ \\
\hline Societal benefit & $4, \mathrm{~s} 1-4, \mathrm{p} 3(\mathrm{k}=6)$ & -0.19 & $<.001^{*}$ \\
\hline Moral goodness & All $(\mathrm{k}=11)$ & -0.16 & $<.001^{*}$ \\
\hline Disgust & $4, \mathrm{~s} 1-4, \mathrm{p} 3(\mathrm{k}=6)$ & 0.05 & .306 \\
\hline Anger & $4, \mathrm{~s} 1-4, \mathrm{p} 3(\mathrm{k}=6)$ & 0.05 & .17 \\
\hline Perceived genetic change & $2,3, \mathrm{~s} 1-4, \mathrm{p} 3, \mathrm{gd} 2(\mathrm{k}=8)$ & 0.05 & .09 \\
\hline
\end{tabular}




\section{RECENCY NEGATIVITY}

Figure 2. Standardized mean differences for willingness to consume a modified crop across 11 studies. A negative difference indicates lower willingness to consume recently modified crops.

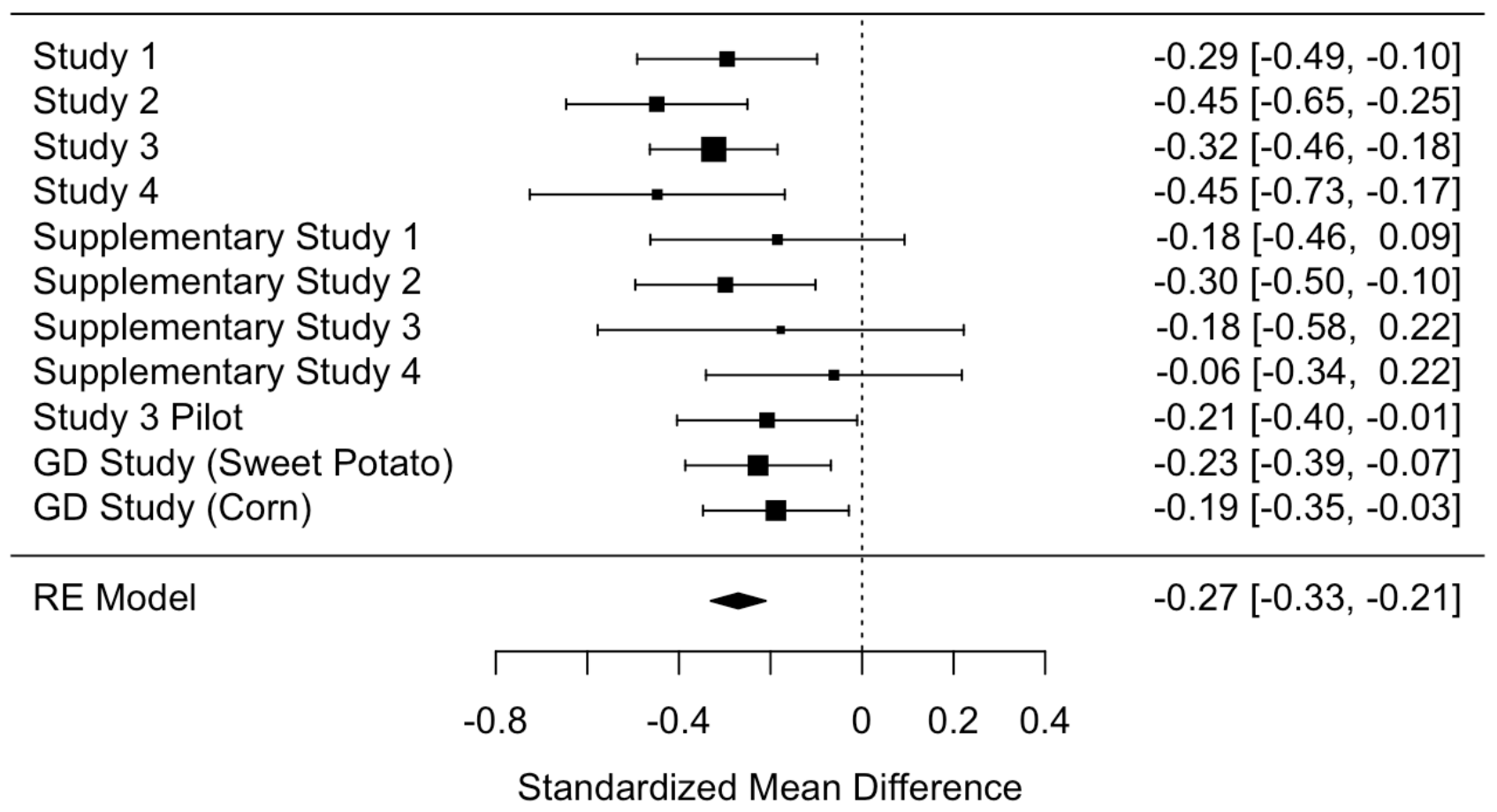

\section{General Discussion}

Across four studies (and a meta-analysis including another seven), we find a robust effect of time on consumer acceptance of food crops: more recently modified crops are less accepted. This phenomenon, which we call recency negativity, holds for different genetic modification techniques (artificial selection, natural or human produced radiation, and genetic engineering) and emerges both in between-subjects and within-subjects comparisons. The robustness to a within-subject design suggests that people believe that recency normatively should affect their judgments.

This raises the question of whether recency negativity is defensible on normative grounds - that is, is it reasonable to be more skeptical of recently-developed crops? GE crops in particular undergo an extensive testing regime before they can legally be sold for human 
RECENCY NEGATIVITY

consumption (NASEM, 2016), and so an aversion to crop recency might seem irrational.

However, on occasion new crops have in fact proved dangerous. One example is the Lenape potato, a conventionally-bred potato that was recalled from agricultural production because it contained dangerously high levels of the toxic alkaloid solanine (Koerth-Baker, 2013). It is therefore reasonable to be somewhat more skeptical of a recent crop than one that has been consumed for decades, presumably without negative consequences - this could be described as the "test-of-time principle." An alternative account is that recency negativity is not due to a consequence of recency, but rather that recency itself is the critical variable. In other words, people may use a heuristic that older is safer-defining "heuristic" as a mental rule of thumb that generally has a reasonable basis, but is also often over-applied (Gilovich, Griffen, \& Kahneman, 2002). We call this the "mere-recency heuristic."

In our view, recency negativity is most likely a mix of both logically-defensible reasoning about risk (i.e, the test-of-time principle) and a mere-recency heuristic. If, as we suggest, both processes are at work, one would expect that a crop that was developed in the past—but has not been grown for consumption until recently — to be seen as intermediate between crops developed in the past (and consumed since then) and those developed only recently. This is because the test-of-time principle focuses on how long the crop has been consumed widely (allowing any lurking risks to be discovered), whereas a mere-recency heuristic would be sensitive to the fact that some crops were developed longer ago (regardless of when they started being widely consumed).

We conducted two studies to test this idea, one asking participants about a sweet potato variety produced by natural radiation, the other asking about a corn variety produced by artificial radiation (both are reported in detail in the Supplemental Material). We described three cases 
RECENCY NEGATIVITY

(between participants): in the first, the crop had been developed in the past (either 100 or 200 years ago) and consumed since then; in the second, the crop had been developed only recently; in the third, the crop had been developed in the past (either 100 or 200 years ago) but had not been grown for human consumption until recently. In both studies, participant's willingness to consume the crop was highest when it had been developed in the past and consumed since, lowest when the crop was developed recently, and intermediate when the crop had been developed in the past but consumed starting only recently. However, although the omnibus effect of condition was significant in both studies, the difference between the intermediate condition and the other two was not consistently statistically significant.

As in Studies 1-4, we also asked four other questions (morality, naturalness, personal, and societal risk). The overall pattern of results was mixed but generally supportive of our hypothesis. For all 10 comparisons ( 5 questions by 2 crops) the recent crop was rated directionally less favorably than the older crop, although these differences were not consistently statistically significant. In 7 of 10 cases, the "old but only recently consumed" version was intermediate between recent and old. One possible explanation for these mixed results is that given the expected effect sizes for differences between recent and old crops for these items $(d \mathrm{~s}$ between .15 and .24; see Table 12), even a small amount of sampling error will overwhelm any true difference between the intermediate condition and the other two. In an attempt to reduce random error as much as possible, we performed an exploratory analysis in which we combined the two studies and standardized and averaged the five questions into a single composite. The per-condition means were as our account predicted $\left(M_{\text {new }}=-.07, M_{\text {old }}\right.$ recently consumed $=.008, M_{\text {old }}=$ .06 ), and the omnibus effect of time was significant, $F(2,1,822)=4.59, p=.01$ (this analysis also controlled for main effects of study). However, even in the combined analysis the pairwise 
RECENCY NEGATIVITY

differences between the intermediate condition and the two others were not significant (intermediate vs. old, $p=.22$; intermediate vs. new, $p=.08$ ).

Overall, then, evaluations of the crop in the "intermediate" condition (in which the crop was developed in the past but consumed only recently) generally fell between evaluations of the crop in the other two conditions. However, the pairwise tests were not statistically significant in either study, so we can neither reject the null that the intermediate crop is disliked as much as the recently-developed crop (which is what test-of-time principle would predict), nor the null that the intermediate crop is liked just as much as the old crop (which is what the mere-recency heuristic would predict). This might be scored as a point in favor of each account (and, perhaps, as consistent with the idea that both are operating). However, the non-significant pairwise tests also mean that that we did not observe statistically convincing evidence of differences predicted by each account (between the intermediate and old crop in for the test-of-time principle, and between the intermediate and new crop for the mere-recency heuristic). We therefore see these results as suggestive, but we believe further research is required to better understand the contributions of both the test-of-time principle and the mere-recency heuristic to recency negativity.

One surprising result is the extent to which recency negativity generalized across crop production techniques, including conventional breeding (i.e., artificial selection). To be sure, there were also sometimes main effects of production technique, as in Study 2, where conventionally-bred crops were preferred to those produced using artificial radiation. However, there were never interactions between production techniques and time, indicating that time affects crop perceptions equally regardless of how those crops were produced. A priori, one might have expected that recency would be especially aversive for less familiar, more invasive, 
RECENCY NEGATIVITY

or more technologically sophisticated crop production methods. The fact that this was not the case suggests the operation of a general process, rather than something specific to crops already perceived as unnatural. It is of course possible that if a crop or production technique is viewed highly positively, recency might not be negative. But, for the range of crops and production techniques we tested, we did not find any systematic exceptions to the recency negativity rule.

\section{Constraints on Generality}

It remains to be seen whether recency negativity generalizes to non-Western populations, given that our samples were all U.S.-only. The preference for "natural" foods and skepticism of new crop production techniques such as GE is prevalent in the West, and is, if anything, stronger in Europe than the US (Gaskell, Bauer, Durant \& Allum, 1999; Román, Sánchez-Siles \& Siegrist, 2017; Rozin, 2005; Scott, Inbar, Brossard, \& Rozin, 2018). We are therefore confident that the current findings would generalize to other Western countries. We are less confident that they would generalize to developing countries, where new crops might be seen as life-saving innovations rather than threats, and we hope future research will address this important question.

In the current studies, we tested attitudes towards two hypothetical crops: sweet potatoes and corn. We have no reason to think that these two crops differ systematically from others that we might have examined, especially because Rozin (2005) shows similar naturalness effects across a range of domesticated or artificially produced plant and animals. Nonetheless, future research should examine the robustness of recency negativity across other crops. It would be particularly useful to employ a stimulus sampling approach (Judd, Westfall, \& Kenny, 2012) in order to quantify how much recency negativity varies across different crop types.

\section{Implications for Public Attitudes}




\section{RECENCY NEGATIVITY}

In developed countries, recency negativity may be broad enough to partly explain public resistance to crops produced using techniques other than conventional breeding. In Study 2, participants rated a recently-produced conventionally-bred crop very similarly to one produced using gamma rays 100 years ago. If people reasonably assume that crops produced by more sophisticated genetic modification techniques are newer, this, rather than any intrinsic feature of the modification technique, may be enough to make these crops suspect. Conversely, public communication of the history of controversial crops may shift attitudes. Some commonly-used genetically engineered crops_-for example, Bt-producing corn—were first approved in the United States over twenty years ago (NASEM, 2016). Based on the current results, we expect that highlighting this fact ought to increase consumer acceptance, at least for foods made with that specific crop. Emphasizing time may thus be an overlooked way to reach consumers who are inclined to reject what they see as a novel, and therefore risky, product. 


\section{RECENCY NEGATIVITY}

\section{References}

Adli, M. (2018). The CRISPR toolkit for genome editing and beyond. Nature Communications, 9, 1911.

Ahloowalia, B. S., Maluszynski, M., \& Nichterlein, K. (2004). Global impact of mutationderived varieties. Euphytica, 135, 187-204.

Arvola, A., Lähteenmäki, L., \& Tuorila, H. (1999). Predicting the intent to purchase unfamiliar and familiar cheeses: the effects of attitudes, expected liking and food neophobia. Appetite, 32, 113-126.

Billing, J., \& Sherman, P. W. (1998). Antimicrobial functions of spices: why some like it hot. The Quarterly Review of Biology, 73, 3-49.

Boyd, R., \& Richerson, P. J. (1985). Culture and the evolutionary process. Chicago, IL: University of Chicago Press.

Cox, D. N., \& Evans, G. (2008). Construction and validation of a psychometric scale to measure consumers' fears of novel food technologies: The food technology neophobia scale. Food Quality and Preference, 19, 704-710.

Evans, G., Kermarrec, C., Sable, T., \& Cox, D. N. (2010). Reliability and predictive validity of the Food Technology Neophobia Scale. Appetite, 54, 390-393.

Fernbach, P. M., Light, N., Scott, S. E., Inbar, Y., \& Rozin, P. (2019). Extreme opponents of genetically modified foods know the least but think they know the most. Nature Human Behaviour, 3, 251-256.

Fischhoff, B., Slovic, P., Lichtenstein, S., Read, S., \& Combs, B. (1978). How safe is safe enough? A psychometric study of attitudes toward technological risks and benefits. Policy Sciences, 9, 127-152. 
RECENCY NEGATIVITY

Frewer, L. J., van der Lans, I. A., Fischer, A. R. H., Reinders, M. J., Menozzi, D., Zhang, X . . Zimmerman, K, L. (2013). Public perceptions of agri-food applications of genetic modification - A systematic review and meta-analysis. Trends in Food Science \& Technology, 30, 142-152.

Gaskell, G., Bauer, M. W., Durant, J., \& Allum, N. C. (1999). Worlds apart? The reception of genetically modified foods in Europe and the U.S. Science, 285, 384-387.

Gaskell, G., Allum, N., Wagner, W., Kronberger, N., Torgersen, H., Hampel, J., \& Bardes, J. (2004). GM foods and the misperception of risk perception. Risk Analysis, 24, 185-194.

Gilovich, T., Griffin, D., \& Kahneman, D. (Eds.). (2002). Heuristics and Biases: The Psychology of Intuitive Judgment. Cambridge: Cambridge University Press.

Guleria, P., Kumar, V., \& Guleria, S. (2017). Genetic engineering: A possible strategy for Protein-Energy malnutrition regulation. Molecular Biotechnology, 59, 499-517.

Henrich, J., \& Henrich, N. (2010). The evolution of cultural adaptations: Fijian food taboos protect against dangerous marine toxins. Proceedings: Biological Sciences, 277, 37153724.

Hsee, C. K., Loewenstein, G. F., Blount, S., \& Bazerman, M. H. (1999). Preference reversals between joint and separate evaluations of options: A review and theoretical analysis. Psychological Bulletin, 125, 576-590.

Judd, C., Westfall, J., \& Kenny, D. (2012). Treating stimuli as a random factor in social psychology: A new and comprehensive solution to a pervasive but largely ignored problem. Journal of Personality and Social Psychology, 103, 54-69. 
RECENCY NEGATIVITY

Klümper, W., \& Qaim, M. (2014). A meta-analysis of the impacts of genetically modified crops. PLoS One, 9, e111629.

Koivisto, U., \& Sjödén, P. (1996). Food and general neophobia in Swedish families: Parent-child comparisons and relationships with serving specific foods. Appetite, 26, 107-118.

Matin, A. H., Goddard, E., Vandermoere, F., Blanchemanche, S., Bieberstein, A., Marette, S., \& Roosen, J. (2012). Do environmental attitudes and food technology neophobia affect perceptions of the benefits of nanotechnology? International Journal of Consumer Studies, 36, 149-157.

Moon, W., \& Balasubramanian, S. K. (2004). Public attitudes toward agrobiotechnology: The mediating role of risk perceptions on the impact of trust, awareness, and outrage. Review of Agricultural Economics, 26, 186-208.

Narayanan, N., Beyene, G., Chauhan, R. D., Gaitán-Solis, E., Gehan, J., Butts, P . . Taylor, N. J. (2019). Biofortification of field-grown cassava by engineering expression of an iron transporter and ferritin. Nature Biotechnology, 37, 144-151.

National Academies of Sciences, Engineering and Medicine (NAS). (2016). Genetically engineered crops: experiences and prospects. Washington, DC: The National Academies Press.

Navarrete, C. D., \& Fessler, D. (2003). Meat is good to taboo: Dietary proscriptions as a product of the interaction of psychological mechanisms and social processes. Journal of Cognition and Culture, 3, 1-40.

Perry, R. A., Mallan, K. M., Koo, J., Mauch, C. E., Daniels, L. A., \& Magarey, A. M. (2015). Food neophobia and its association with diet quality and weight in children aged 24 
RECENCY NEGATIVITY

months: a cross sectional study. International Journal of Behavioral Nutrition and Physical Activity, 12, 13.

Pliner, P. (1982). The Effects of Mere Exposure on Liking for Edible Substances. Appetite, 3, 283-290.

Pliner, P., Lähteenmäki, L., \& Tuorila, H. (1998). Correlates of human food neophobia. Appetite, 30, 93.

Román, S., Sánchez-Siles, L. M., \& Siegrist, M. (2017). The importance of food naturalness for consumers: Results of a systematic review. Trends in Food Science \& Technology, 67, 44-57.

Roth, R. E. (2007). Repugnance as a constraint on markets. Journal of Economic Perspectives, $21,37-58$.

Rozin, P. (2005). The meaning of "natural": Process more important than content. Psychological Science, 16, 652-658.

Rozin, P., Cohen, A., \& Ruby, M. (2019). Food and eating. Chapter in: S. Kitayama \& D.Cohen (eds.). Handbook of Cultural Psychology, second edition, pp. 447-477. New York: Guilford.

Scott, S. E., Inbar, Y., \& Rozin, P. (2016). Evidence for absolute moral opposition to genetically modified food in the United States. Perspectives on Psychological Science, 11, 315-324.

Scott, S. E., \& Rozin, P. (2017). Are additives unnatural? Generality and mechanisms of additivity dominance. Judgment and Decision Making, 12, 572-583.

Scott, S. E., Inbar, Y., Wirz, C. D., Brossard, D., \& Rozin, P. (2018). An overview of attitudes toward genetically engineered food. Annual Review of Nutrition, 38, 459-479. 


\section{RECENCY NEGATIVITY}

Siegrist, M. (1999). A causal model explaining the perception and acceptance of gene technology. Journal of Applied Social Psychology, 29, 2093-2106.

Siegrist, M. (2000). The influence of trust and perceptions of risks and benefits on the acceptance of gene technology. Risk Analysis, 20, 195-204.

Sjöberg, L. (2008). Modified food in the eyes of the public and experts. Risk Management, 10, 168-193.

Slovic, P., Fischhoff, B. \& Lichtenstein, S. (1984). Behavioral decision theory perspectives on risk and safety. Acta Psychologica, 56, 183-203.

Slovic, P., Fischhoff, B. \& Lichtenstein, S. (1985). Characterizing perceived risk. In: Kates, R. W., Hohenemser, C., \& Kasperson, J. X. (Eds.), Perilous progress: Managing the hazards of technology. Westview, Boulder, Colorado, pp. 91-124.

Tang, G., Qin, J., Dolnikowski, G. D., Russel, R. M., \& Grusak, M. A. (2009). Golden Rice is an effective source of vitamin A. The American Journal of Clinical Nutrition, 89, 17761783.

The New Food Fights: U.S. Public Divides Over Food Science. Pew Research Center, Washington, D.C. (2016). http://www.pewinternet.org.proxy1.lib.uwo.ca/2016/12/01/thenew-food-fights/

Traill, B. W., Yee, W. M., Lusk, J. L., Jaeger, S. R., House, L. O., Morrow Jr., J. L . . Moore, M. (2006). Perceptions of the risks and benefits of genetically-modified foods and their influence on willingness to consume. Food Economics - Acta Agriculturae Scandinavica, Section C, 3, 12-19.

Vidigal, M., Minim, V., Simiqueli, A., Souza, P., Balbino, D., \& Minim, L. (2015). Food technology neophobia and consumer attitudes toward foods produced by new and 
RECENCY NEGATIVITY

conventional technologies: A case study in Brazil. LWT-Food Science and Technology, $60,832-840$.

Viechtbauer, W. (2010). Conducting meta-analyses in R with the metafor package. Journal of Statistical Software, 36, 1-48.

Wieczorek, A. M., \& Wright, M. G. (2012). History of Agricultural Biotechnology: How Crop Development has Evolved. Nature Education Knowledge, 3, 9.

Yang, X., Hu, R., Yin, H., Jenkins, J., Shu, S., Tang, H . . Liu, D. (2017). The Kalanchoë genome provides insights into convergent evolution and building blocks of crassulacean acid metabolism. Nature Communications, 8, 1899.

Zajonc, R. B. (1968). Attitudinal effects of mere exposure. Journal of Personality and Social Psychology, 9, 1-27.

Zohary, D., Hopf, M., \& Weiss, E. (2012). Domestication of Plants in the Old World: The Origin and Spread of Domesticated Plants in Southwest Asia, Europe, and the Mediterranean Basin (4th ed.). Oxford: Oxford University Press. 